\title{
The Art of Making Mistakes
}

\author{
Cedric vanEenoo
}

\begin{abstract}
By its nature, art cannot be without mistakes, although no s ingle definition of art can be found. It is a process of expression of the world through the work of a creator. To the credit of many miscalculations and errors made by artists all through time, we a re gifted with masterpieces of art and inventions. The emergence of the unexpected through the process of creation turns to be an aesthetic matter. What are the limits of different communicative languages of art media or their conflicting probabilities of creating errors aesthetically called unexpected objects?
\end{abstract}

Keywords Art, Mistakes, Meaning, Misunderstanding, Errors, Failure

Mistakes in art are ubiquitous. The purpose of this article is not to show how we can learn from them, but firstly to witness how incidents can bring fresh perspectives to the field of art. Moreover, and specifically, this article aims at observing what meaning errors can convey.

What we may consider an error is to the great minds of art another step closer to a great finding.

Before focusing on Art, science is a meaningful source of observation: Thomas Edison, the great inventor with over 1000 patents to his name, the inventor to whom we owe the light bulb, telegraph and many others, is probably as famous for his skill as he is for his blunders. In fact, he is said to have made many bulbs before finally getting one to work... unexpectedly. The talking machine, another one of his discoveries, was discovered by accident. (Windsor 1924).

Michelangelo Di Ludovico Buonarroti Simon etched his name to the history of art by his powerful works. His famous paintings and sculptures were an expression of how he saw the world. In the Sistine Chapel paintings (1508 to 1512), the Pope Leo X wanted the ceiling painted with 12 apostles. He spent four years working in uncomfortable postures to create the three hundreds paintings of the chapel's ceiling. The artwork was done when the plaster was wet (Matterin 2005, p.24), resulting in a unique representation of light and colors. In the end, he unveiled a new era in art and was applauded and criticized as much. Since he was more a sculptor than a painter, he had to repeat some of the painting at some point:

"His first panel was ruined by the buildup of salts and efflorescence on the surface of the pinging, and when he worked with too wet surface he soon found mold and mildew discoloring fresco. Such mistakes could not be simply corrected or painted over. Michelangelo had to chip away the entire fresco in order to restore on the tumulus Noah and the Flood, a project that had taken him six weeks." (King 2003).

Like in most of his life's work, most of his painting was nudes, and being in a church it obviously attracted a lot of criticism. He debates of whether right or wrong and the means of expression used like the much criticized masculine arms of women in the church ceiling that have come to earn Michelangelo's painting a unique touch and character through history. From his orthodox methods, his creation became a one-of-a-kind artwork.

What was seen as controversy in one generation was received in a different perspective by another. As the society changed and loosened its stance on various issues, the opinion changed; so did the judgment on the artist's work. Michelangelo's style of doing nude sculptures often earned his work's censorship.

Sometimes there is much more to be read in a mistake other than the artists' inadequacies. Leonardo Da Vinci is the father of many inventions. Among them was a military tank whose design that was found from his sketches contained a miscalculation. Although ahead of its time, the tank was almost functional apart from its front and back wheels rotated against each other. Perhaps the flaw was a gift in disguise: the artist distrusted the intentions of its users.

"We shall never know whether this was a deliberate mistake made by a man with a conscience or to prevent the design from being useful to enemies." (Smith 1985, p. 29).

Beyond the practical concerns, to err is to discover.

The Mona Lisa, one of the world's most famous paintings has been a subject of debate for the half smile of the character the painting depicts. This so called defect has earned the masterpiece an identity.

Pablo Picasso embraced his mistakes from his childhood: when he was 17, the artist was said to love bullfighting as a passion. He would do paintings a day before the event and sell them to earn a ticket to the Corrida. In his first attempt to create a copperplate etching of a picador in the bullring, he forgot that his image would be reversed, but the error did not make Picasso use the painting any less, he simply named it the left handed one (McNeese 2006, p.9). There is a clever position for an artist in the acknowledgment of his errands. It is through the curiosity and naivety of Pablo Picasso and his friend Georges Braque from 1907 that cubism was born. Being a new form of art, it was not spared by critics either. In 
fact, its name cubism was coined from a critic's comments, Louis Vauxcelles, who used the term "bizarre cubiques" to refer to a picture by Braque. (Gombrich 1960).

Miscalculation and the unexpected reception of an artwork convey a message.

Marcel Duchamp etched his name in the history of art by defying what was considered normal achievement in his day. From his early works, Duchamp did not leave controversy far behind. His painting dubbed Nude Descending a Staircase, in 1912, was rejected for its tattle. He was requested by a jurist in the gallery to either withdraw his work or rename it to something less provocative, a request he politely declined and chose to leave with the painting. The mistake was not within the artwork itself but in the choice of where to exhibit it. This misjudgment led to misunderstanding of the audience at the time; hence controversy. As it was later quoted of him, it was really a turning point in his life, after which he was not interested in groups. (Tomkins 1996). The following year, 1913 the artist decided to present his work to an exhibition dubbed the Amory Show, which was held in New York City. The painting was ridiculed by the majority of the visitors, from cartoonists to columnists. The painting was heavily criticized "an explosion in a shingle factory" as the New York Times described it (Tomkins 1996 p.116). Further than just the misunderstanding, his most high profile critic was probably the American President Theodore Roosevelt, who called it "A naked man going downstairs". The president compared the painting to a Navajo rug in his bathroom. For him the Rug was more artistic than the painting. This is representative of the attitude of the upper class when first introduced to Cubism and futurism" (Roosevelt 1913). The point in this case is to observe how deviations can be part of the creative process, and in what extends it can also be found from the audience. Furthermore, and as a result, the concept of creating via errors belongs to artists as much as they depend on the public.

To his generation Duchamp's works were nothing short of lost, many years later the lost artist is viewed as having lead into a new era of art. Not cowed by all the criticism attracted by his work, Duchamp was not to be stopped. Although he had joined the anti-art movement Dada, Duchamp did not quite producing. In 1917, Duchamp bought a urinal which he took to his studio and by rotating it by ninety degrees, signing on it "R Mutt" and declared it art. (Tomkins 1996). By so doing, Duchamp opened a new door for art with what would later be voted as the most influential artwork of the 20th century, by five hundreds British professionals in 2004 . The Urinal was firstly rejected by the Society of independent artists on the basis that it was not art. Duchamp took the criticism that followed with a taste of humor:

"People took modern art very seriously when it first reached America because they believed we took ourselves very seriously. A great deal of modern art is meant to be amusing."

He told a New York newspaper. (Dorment 2001, p. 10). From that on, Duchamp's fountain created a whole new era in conceptual art.

When facing the inadvertent, one must forget the expertise, the skillfulness and the regulations to open to uncommon reality and discoveries.

Blunders in art are often the starting point of very innovative concepts and original artworks. Many a creator based his project and style on a misunderstanding, a failure or farce. Mistakes reveal what we do not expect, hence, what the artist is really looking for in his research.

"Go on failing. Go on. Only next time, try to fail better" (Beckett 1966).

With errors comes a certain energy, it brings a smile, a distance, a new view. Parody is a powerful tool for example, and it comes with mocking an artwork, referring to what goes wrong. It appeals to our critical judgment, and so do mistakes. Hence, it is important to allow a certain space for the unexpected:

"I've spent my life making blunders" (Cardullo 2005).

Unexpected events in an artwork convey a loss of domination, a loss of limitation, and a loss of constraint. Mistakes are fascinating: they carry a one-of-a-kind style, recognizable and without equal, because they rely on the fact that mistakes cannot be reproduced to the same. Errors have this special feature to be absolutely extraordinary, and for that particular reason, they are invaluable and meaningful.

There is a unique aesthetic in disorder: in Black cat White Cat, Emir Kusturica is working with chaotic organizations of scenes: background and foreground are confused, objects are falling, and actors are imperfect. But that approach creates a unique atmosphere of mayhem and the very poetry of his artwork. This energy spreads to the audience. The singular style of the movie relies on the process and the utilization of what could be considered mistakes.

An error in an artwork creates a feeling that something is possible; it is an open window to something we do not control. And the contemplation of these mistakes gives us a power. This space where the unknown becomes reachable is precious: we are to be surprised and astonished by the poetry of the unexpected.

Mistakes are always made in a short period of time. From this aspect comes their rarity and their value. Like gold, they are to be found, and not conceived. A false move in a painting is the lucky accident that leads to the flash of genius. Unintended moves are the purpose of many an artist. The faux pas is not a delusion but the proof that we are in need of omission and miscalculation to contemplate and to sublimate the goal of art, and to go beyond the boundaries.

It is important to observe how incidents can bring fresh perspectives and concerns. When something unexpected occurs, it opens a door to new possibilities. Mistakes can reveal a unique and precious opportunity to truly participate in the process of creation without the interference of knowledge and skills.

There is a particular aesthetic in disorder. In Black cat White Cat, Emir Kusturica is working with chaotic organizations of scenes: background and foreground are confused, objects are falling, actors are clumsy. But this 
approach creates a unique atmosphere and the very poetry of his work. The singular style of the movie relies on the process and the utilization of what could be considered imperfections, or even failures.

It is an open window to something we do not control and the contemplation of these mistakes gives us a freedom of interpretation. There is beauty in errors, because of its truly human vibration.

Unexpected events in an artwork convey a loss of domination, a loss of limitation, and a loss of constraint. Mistakes carry a one-of-a-kind style, recognizable and without equal, because they rely on the fact that they cannot be reproduced to the same. Therefore, bringing their uniqueness to the art. Hence, it is important to allow a certain space for the unexpected. This project aims at utilizing mistakes in the process of creation by alteration of the narrative.

Director John Cassavetes is known for pushing the limits of the performers in improvised scenes, based on how they perceive the scenario and the character they play (Carney 1994, p. 154). They are given freedom of performance, focusing on a presence of acting to communicate emotions, widening the spectrum of interpretation and offering more than the written story. In his film Shadows, it seems as if the protagonists embody the story, becoming the plot themselves, in a choreographic balance with the omnipresent jazz music (Shadows 1959). Improvisation is a method used by a variety of directors, from very diverse backgrounds and practices, but very often it is used as a supplementary instrument, in close relation with the scenario. Improvisation is a strategy to obtain more sincere performances from the actors (Wexman 1980). But it can also make the scenes more compelling and captivating. This approach could be used in the filming itself, to infuse authenticity in the narrative and benefit from the intensity of the moment. In this regards, it allows for unexpected happening during the performance.

Whether art is right or wrong is therefore a debate we, the audience can win, as we judge by the skill and knowledge or ignorance of our times, whereas art is timeless. What a president considered to be not art becomes acclaimed by critics and scholars many years later. The misunderstanding or misjudging can be on both sides: artist and public. Art takes these errors further and transcends them to sublimate the art piece. There is a loss of control over the artwork in this process. That is where the power of art lies: the unexpected.

"The process of creating a masterpiece cannot be done without error. Art is a step from what is obvious and well-known toward what is arcane and concealed" (Gibran 1997).

As this paper has illustrated, mistakes and art go hand in hand. The failures in art shall be celebrated today, for tomorrow they will define a masterpiece. Furthermore, they give art its very meaning of revolution and evolution. "What I expect from any work of art is that it surprises me, that it violates my customary valuations of things and offers me other, unexpected ones" (Selz 1981).
Away from lessons for improvement, as described in Better by Mistake, by Alina Tugend (Tugend 2011) looking at mistakes as a way to learn, what turns out to be the paramount of errors is the reality that artists, like most of us, tend to avoid mistakes. All the instances of unexpected rhymes in the completed non-rhymed poetry by J. Thomas Shaw (Shaw 1994) present a more poetic approach. The example points out how the constraints of control can deny creativity; and how being free from the limitations of language, art can transcend the boundaries. David Graver emphasizes this limitation matter, explaining that the expected aesthetic of an artwork becomes a guideline, of which one can divest himself in the process of creation. Mistakes represent an aesthetic approach and a style, by not respecting the process of production, as stated in Annette W. Balkema \& Henk Sager's Exploding Aesthetics (Balkema \& Sager 1924). The question remains in the honesty of the artist. As stated by Jacques Derrida: it is in freedom that an artist expresses oneself.

\section{REFERENCES}

[1] Balkema A. W. \& Sager, H. 2000, Exploding Aesthetics; Series of Philosophy of Arts and Art Theory, Rodopi, Amsterdam.

[2] Black Cat, White Cat 1999, motion picture, Focus Features, Universal City.

[3] Cardullo, B. 2005, Interviews (Conversations with Filmmakers), University Press of Mississippi, Ridgewood.

[4] Derrida, J. 1987, The truth in painting, University of Chicago Press, Chicago.

[5] Dorment, R. 2001, The Telegraph, Byline, London.

[6] Gibran, K., 1997, The prophet, Wordsworth Editions.

[7] Gombrich, E. 1960, Art and illusion, Princeton University Press, Princeton.

[8] Graver, D., 1995, The aesthetics of disturbance: Anti-art in avant-garde drama, University of Michigan Press, Ann Arbor.

[9] King, R. 2003, Michelangelo and the Pope's Ceiling, Penguin, London.

[10] McNeese, T. 2006, 'Pablo Picasso', Chelsea House Publications, New York City.

[11] Matterin, J. 2005, Michelangelo, Checkerboard Library, Fairless Hills.

[12] Smith, C.G. 1985, The Inventions of Leonardo Da Vinci, Peerage Books, London.

[13] Selz, P. H. 1981, The Work of Jean Dubuffet, The Museum of Modern Art Publications, Stratford.

[14] Shadows 1959, motion picture, The Criterion Collection, New York City. 
[15] Shaw, J. T. 1994, Pushkin's Poetics of the Unexpected, Slavica Publishers, Bloomington.

[16] Tomkins, C. 1996, Duchamp: A Biography, Holt Paperbacks, New York City.

[17] Tugend, A. 2011, Better by Mistake: The Unexpected Benefits of Being Wrong, Riverhead Books, New York City.
[18] Wexman, V.W., 1980, 'The rhetoric of cinematic improvisation', Cinema Journal, pp. 29-41.

[19] Windsor, H. H. 1924, 'Popular Mechanics Magazine', vol.42, no.3, p.470, Hearst Magazines, New York City. 